\title{
NEW RECORDS OF DESMOULIN'S WHORL SNAIL VERTIGO MOULINSIANA (DUPUY, 1849) (GASTROPODA: EUPULMONATA: VERTIGINIDAE) IN NORTH-WESTERN POLAND
}

\author{
ANNA LIPIŃSKA \\ Institute of Nature Conservation Polish Academy of Sciences, Mickiewicza 33, 31-120 Cracow, Poland \\ (e-mail: lipinska@iop.krakow.pl); (1) https://orcid.org/0000-0003-4065-1863
}

\begin{abstract}
Vertigo moulinsiana (Dupuy) is a small, endangered species of European land snail. It has been placed on the Red List of Threatened Species in Poland, the IUCN Red List of Threatened Species and is protected in the EU by the Habitats Directive. More than 90 localities of $V$. moulinsiana are known in Poland. Six new localities of the species have been found in the north-west of the country. The populations in the new localities are extremely abundant, and one of them was the most abundant of all the species' populations covered by the GIOS Polish State Environmental Monitoring Programme. Also V. angustior Jeffreys was found in this area.
\end{abstract}

KEY WORDS: terrestrial snails; wetlands; endangered species; Habitats Directive

\section{INTRODUCTION}

Desmoulin's whorl snail Vertigo moulinsiana (Dupuy, 1849) is a small, endangered European land snail species (shell height ca 2 mm; WIKTOR 2004). The species is on the IUCN Red List of Threatened Species, category VU (KILLEEN et al. 2011), and listed in Appendix II of the Habitats Directive. In Poland it enjoys strict species protection (UsTAWA 2004). The species is also listed in the Polish Red Book of Animals in category CR (POKRYSZKO 2004), and has the same category on The Red List of Threatened and Endangered Animals (GŁOWACIŃSKI 2002).

For a long time, Desmoulin's whorl snail in Poland was known from a few records: environs of Białowieża (Stara Białowieża, Uroczysko Knihiniówka and Pogorzelce) and Lubusz Province (Lubniewice near Gorzów Wielkopolski; LIPIŃSKA et al. 2012). In recent years, however, the number of its records has increased substantially, mainly as a result of pre-investment nature inventories. In north-western Poland, this species is very abundant in at least 26 sites, including eight in the province of Wielkopolska (KSIĄŻKIEWICZ 2009). Currently, more than 90 localities of $V$. moulinsiana are known throughout Poland, in the provinces of Wielkopolska, Western Pomerania,
Mazovia, Świętokrzyskie and Podlasie (species monitoring results in 2013-2014; POKRYSZKO et al. 2016). The species is therefore more common in the Polish fauna than it had appeared to be a dozen or so years ago. However, the status of this threatened species remains the same: the greater number of its new localities is a result of an extensive, highly focused survey effort rather than colonisation of new areas.

In Poland, this species occurs in open, calcareous wetlands. It is highly endangered by habitat degradation resulting from changes in hydrological conditions, especially drainage and excessive groundwater intake. Further threats to this species' habitats include eutrophication (pollution by nitrogen compounds), changes in land use, and natural succession (overgrowth of open habitats by trees). Other unfavourable phenomena that locally threaten the habitats are trampling, erection of rural and recreational buildings (KILLEEN 2003, LIPIŃSKA 2010, LIPIŃSKA et al. 2012), and activities such as mowing (KILLEEN 2003). Desmoulin's whorl snail is particularly sensitive to habitat changes because of its strict dependence on sufficiently high level of groundwater (TATTERSFIELD \& MCINNES 2003). 


\section{MATERIAL AND METHODS}

\section{RESEARCH AREA}

The research area is situated in the Bory Kujańskie forests in the Krajeńskie Lake District. Administratively, the Bory Kujańskie are situated in the province of Wielkopolska, the district of Złotów and the commune of Zakrzewo, in the Forestry District of Złotów. Covering an area of ca $50 \mathrm{~km}^{2}$, this forest complex extends between Śmiardów Złotowski in the west and the Łobżonka valley in the east, and from Wersek in the north to Rudna in the south.

The study plot, covering some 52 ha, consists of a series of marshes lying along a ca $4 \mathrm{~km}$-long stretch north of Skic in the valley of the Skicka Struga River (Figs 1-2). Within the study plot, the valley, running from west to east, has high, wooded banks. The river is narrow, partly clogged with reeds and silted up, which probably explains the waterlogging of the meadows adjoining the banks. High water levels have degraded the drainage ditches leading to it.

The knowledge of the fauna of Bory Kujańskie is very fragmentary. The information on vertebrates is sparse, and the only available data on invertebrates relate to beetles (RUTA et al. 2014). In fact, the state of faunistic research here is rudimentary with respect to all groups. It was impossible to find any published information on the malacofauna of the Bory Kujańskie. In recent years, the thick-shelled river mussel Unio crassus has been found in the Łobżonka River, and Pseudanodonta complanata and Unio tumidus in a bay of Lake Borówno. Columella aspera occurs in

\section{RESULTS}

\section{Vertigo moulinsiana (Dupuy, 1849)}

Specimens of Desmoulin's whorl snail were found in all six habitat patches examined in the study plot (Fig. 1).

\section{L o c a 1 i t y $\mathrm{Vm} 1$}

This is an open area of 0.41 ha, covered mainly by sedges Carex sp. (Fig. 3). There was standing water from a few to $15 \mathrm{~cm}$ deep between most of the sedge clumps. The condition of the habitat was appropriate. $V$. moulinsiana was found here at a density of 192 individuals $/ \mathrm{m}^{2}$ (Table 1 ).

\section{L o c a 1 i t y $\mathrm{Vm} 2$}

This is an area of 0.65 ha, situated among trees, supporting mainly sedges Carex sp. and sweet-grass Glyceria maxima (Fig. 3). There was standing water the pine and oak forests on the eastern shore of Lake Borówno, and Helix pomatia has been seen in the park in the village of Kujan (RUTA et al. 2014).

\section{METHODS}

The fieldwork was conducted in November 2018 along a ca $4 \mathrm{~km}$-long stretch of the Skicka Struga River (Fig. 1). Six patches of habitat typical of $V$. moulinsiana were found in the study plot. Sampling points were selected within them, where the vegetation was visually searched for the presence of snails. The method involved counting live individuals found on a ca $0.25 \times 0.25 \mathrm{~m}$ patch of vegetation. At each point, the snails were counted on three separate sedge clumps. The number of sampling points was different at particular localities (depended on the open wetland area of the patch). There were eight in the locality Vm 5 and three in the other ones.

The assessment of population and habitat status was based on the methodology proposed by GIOŚ (The National Environmental Conservation Inspectorate; LIPIŃSKA et al. 2012). V. moulinsiana individuals were neither caught/collected nor sampled, but only counted on vegetation, thus no authorisation for actions subject to prohibition with regard to protected animal species was required. The Chief Inspectorate for Environmental Protection has approved the use of data from the Monitoring database for species and natural habitats for the purposes of this publication (DM / 51-11-04 / 12/19 / MZ).

from a few to $30 \mathrm{~cm}$ deep in most of the spaces between the sedge clumps. The condition of the habitat was assessed as appropriate. The density of V. moulinsiana was found to be 773 ind. $/ \mathrm{m}^{2}$ (Table 1).

Table 1. Occurrence of Vertigo moulinsiana in new localities near Skic (NW Poland)

\begin{tabular}{lcccc}
\hline Localities & N adult & N young & N sum & $\begin{array}{c}\text { Density } \\
\text { N sum } / \mathrm{m}^{2}\end{array}$ \\
\hline Vm 1 & 30 & 6 & 36 & 192 \\
Vm 2 & 114 & 31 & 145 & 773 \\
Vm 3 & 30 & 11 & 41 & 219 \\
Vm 4 & 7 & 3 & 10 & 53 \\
Vm 5 & 102 & 46 & 148 & 296 \\
Vm 6 & 40 & 9 & 49 & 261 \\
\hline
\end{tabular}




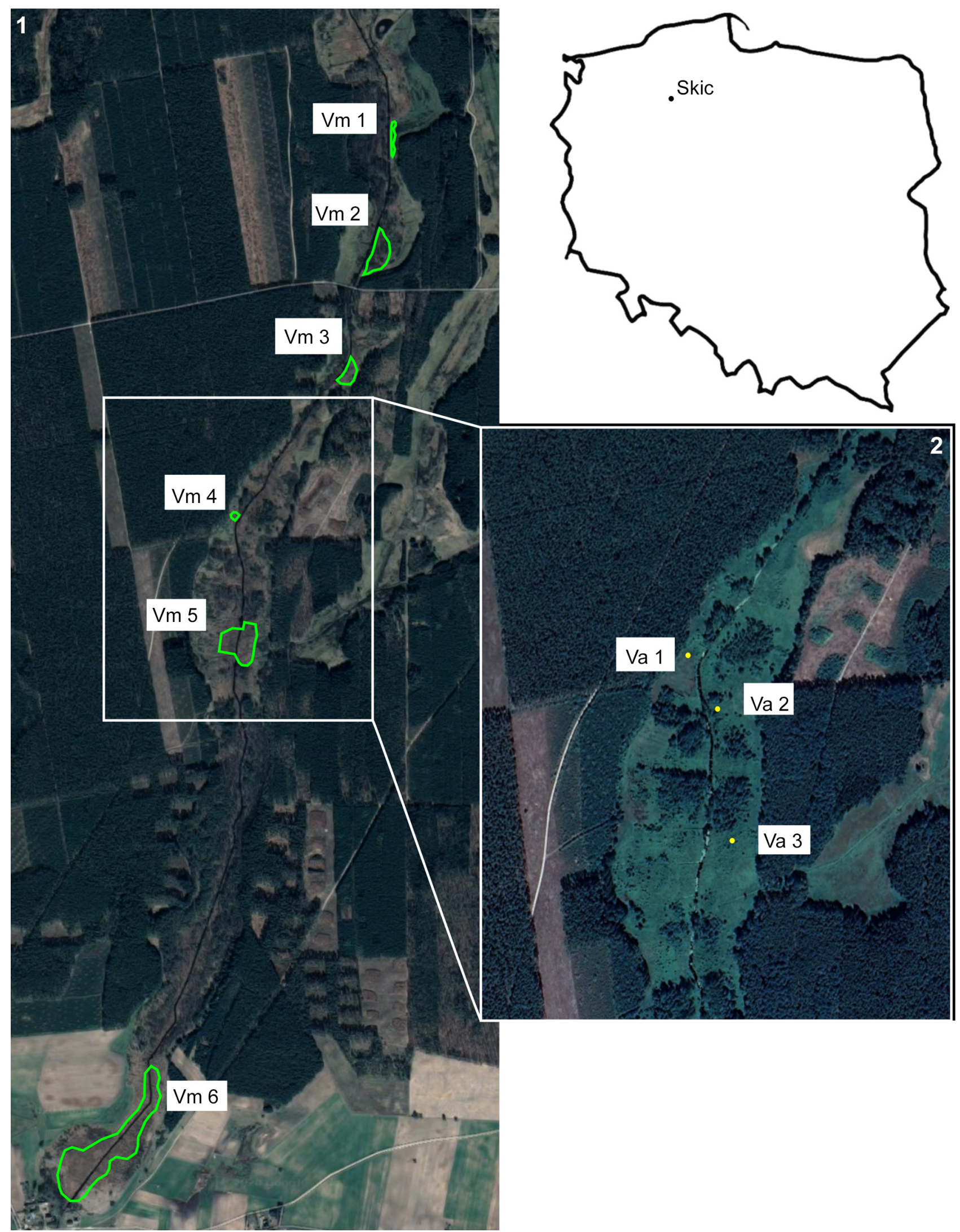

Figs 1-2. Distribution of the new localities at Skic (NW Poland) of: 1 - V. moulinsiana (Vm 1, Vm 2, Vm 3, Vm 4, Vm 5 , Vm 6), $2-V$. angustior (Va 1, Va 2, Va 3). The green lines mark the boundaries of the sites 
L o c a 1 i t y $\mathrm{Vm} 3$

This is an open area of 0.17 ha, covered mainly by sedges Carex sp. (Fig. 3). There was standing water from a few to $20 \mathrm{~cm}$ deep in most of the spaces between the sedge clumps. The condition of the habitat was appropriate. The density of $V$. moulinsiana was 219 ind. $/ \mathrm{m}^{2}$ (Table 1 ).

L o c a 1 i t y $\mathrm{Vm} 4$

This is an open area of 0.07 ha, covered mainly by sedges Carex sp. (Fig. 3). There was standing water a few to $20 \mathrm{~cm}$ deep in most of the spaces between the sedge clumps. The condition of the habitat was appropriate. $V$. moulinsiana was found at a density of 53 ind. $/ \mathrm{m}^{2}$ (Table 1).

\section{L o c a 1 i t y $\operatorname{Vm} 5$}

The area occupied by the population is ca 1 ha. It was found that the farther south, the larger the density. $V$. moulinsiana occurred most abundantly at the southernmost point of the area, where the density was ca 469 ind. $/ \mathrm{m}^{2}$ on the left bank of the river and 155 ind. $/ \mathrm{m}^{2}$ on the right bank. The density was low- est in the northern part of this locality, where only 53 ind. $/ \mathrm{m}^{2}$ were found (Fig. 3). Standing water, from a few to about $20 \mathrm{~cm}$ deep, was present at all the sampling points. The area supported mainly various species of Carex and sweet grass Glyceria maxima (Fig. 3 ). The condition of the habitat was appropriate for this species.

L o c a 1 it y $\mathrm{Vm} 6$

This is an open area of 3.45 ha, covered mainly by sedges Carex sp. There was standing water from a few to $30 \mathrm{~cm}$ deep in most of the spaces between the sedge clumps. The habitat was in good condition. $V$. moulinsiana was found at a density of 261 ind. $/ \mathrm{m}^{2}$ (Table 1).

Compared to other sites of $V$. moulinsiana in Poland, the populations at Skic are very abundant. Currently, 23 sites of this species are surveyed within the framework of the GIOŚ Polish State Environmental Monitoring Programme (Table 2). The results of this research show that locality Vm 2 supports the highest density of individuals per $\mathrm{m}^{2}$ in Poland (Table 2).

Table 2. Densities of V. moulinsiana populations in new localities near Skic (NW Poland; bold) and at all sites of this species covered by the Polish State Environmental Monitoring Programme (data provided by GIOŚ)

\begin{tabular}{|c|c|c|c|}
\hline Locality & Province & Year of study & Density (ind $/ \mathrm{m}^{2}$ ) \\
\hline Brzeźno & Lublin & 2014 & 2 \\
\hline Pasternik Kacze Mydło & Mazovia & 2014 & 88 \\
\hline Pożary KPN & Mazovia & 2014 & 210 \\
\hline Białowieża 1 & Podlasie & 2014 & 62 \\
\hline Białowieża 2 & Podlasie & 2014 & 4 \\
\hline Stara Białowieża & Podlasie & 2014 & 2 \\
\hline Potopy & Podlasie & 2014 & 12 \\
\hline Nowy Dwór & Podlasie & 2014 & - \\
\hline Foltyny & Silesia & 2014 & - \\
\hline Mosty & Świętokrzyskie & 2014 & - \\
\hline Rybnica & Świętokrzyskie & 2014 & 37 \\
\hline Tyniec & Świętokrzyskie & 2014 & 27 \\
\hline Umianowice Duże & Świętokrzyskie & 2014 & 98 \\
\hline Umianowice Małe & Świętokrzyskie & 2013 & 16 \\
\hline Wólka Bodzechowska & Świętokrzyskie & 2014 & - \\
\hline Sokolica & Warmia-Mazury & 2014 & 3 \\
\hline Jezioro Liptowskie & Western Pomerania & 2013 & 104 \\
\hline Jezioro Tuczno & Western Pomerania & 2013 & 20 \\
\hline Debrzynka 1 & Wielkopolska & 2013 & 12 \\
\hline Debrzynka 2 & Wielkopolska & 2013 & 80 \\
\hline Napachanie & Wielkopolska & 2013 & 104 \\
\hline Samborka 1 & Wielkopolska & 2013 & 40 \\
\hline Samborka 2 & Wielkopolska & 2013 & 16 \\
\hline Skic Vm 1 & Wielkopolska & 2018 & 192 \\
\hline Skic Vm 2 & Wielkopolska & 2018 & 773 \\
\hline Skic Vm 3 & Wielkopolska & 2018 & 219 \\
\hline Skic Vm 4 & Wielkopolska & 2018 & 53 \\
\hline Skic Vm 5 & Wielkopolska & 2018 & 105 \\
\hline Skic Vm 6 & Wielkopolska & 2018 & 261 \\
\hline
\end{tabular}




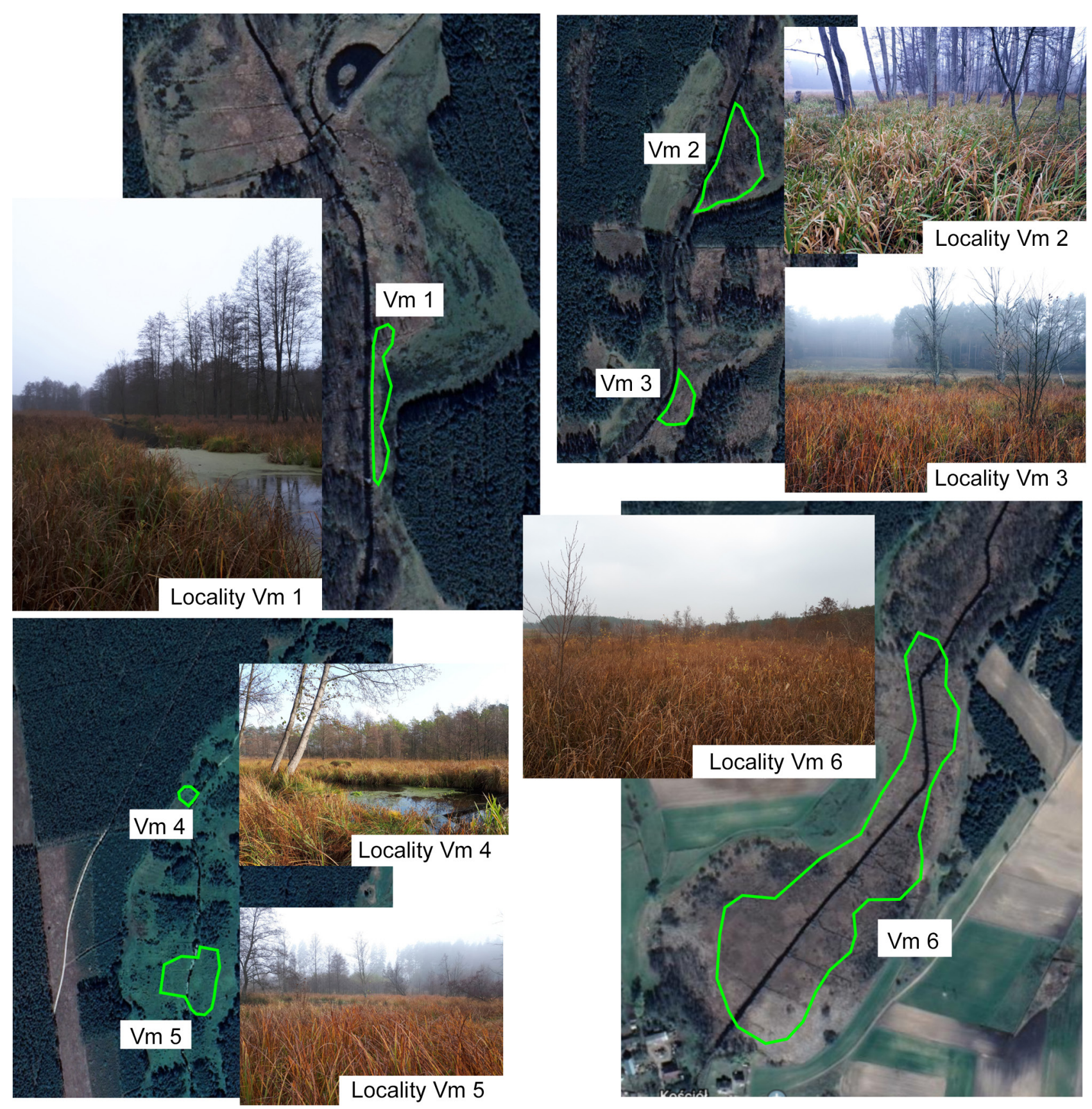

Fig. 3. Location and photographic documentation of the new localities of $V$. moulinsiana $(\mathrm{Vm} 1, \mathrm{Vm} 2, \mathrm{Vm} 3, \mathrm{Vm} 4, \mathrm{Vm}$ 5, Vm 6) at Skic (NW Poland). The boundaries of the sites are shown as green lines. Photo: November 9th, 2018 by ANNA LIPIŃSKA 


\section{Vertigo angustior (Jeffreys, 1830)}

The narrow-mouthed whorl snail $V$. angustior was also found in the study area. However, these were only single individuals (3 in total): one juvenile each in localities Va 1 and Va 2, and a single adult in lo- cality Va 3. The area where the snails were found are marked on the map (Fig. 2).

In Poland, 49 sites of this species are covered by the GIOŚ Polish State Environmental Monitoring Programme, 37 of which are within the country's continental biogeographical region (Table 3).

Table 3. Densities of $V$. angustior from the continental region of Poland covered by the Polish State Environmental Monitoring Programme GIOŚ (data from 2013, 2014 and 2018). New localities are bolded

\begin{tabular}{|c|c|c|c|}
\hline Locality & Province & Year of study & Density (ind $/ \mathrm{m}^{2}$ ) \\
\hline Brodnica & Kujawy-Pomerania & 2014 & 2 \\
\hline Zagórzyńskie Łąki & Lower Silesia & 2014 & 126 \\
\hline Kaczorów & Lower Silesia & 2014 & 4 \\
\hline Brzeźno & Lublin & 2014 & 92 \\
\hline Poleski PN & Lublin & 2014 & - \\
\hline Bobrowa Struga & Lubusz & 2013 & $>12$ \\
\hline Ilanka1 & Lubusz & 2013 & 4 \\
\hline Ilanka2 & Lubusz & 2013 & $>10$ \\
\hline Pliszka & Lubusz & 2013 & $>16$ \\
\hline Brodła1 & Małopolska & 2014 & 156 \\
\hline Brodła2 & Małopolska & 2014 & 46 \\
\hline Oronne & Mazovia & 2014 & 20 \\
\hline Pakosław-Błota & Mazovia & 2014 & 56 \\
\hline Pożary KPN & Mazovia & 2014 & - \\
\hline Hajnówka & Podlasie & 2014 & - \\
\hline Nowy Dwór & Podlasie & 2014 & 86 \\
\hline Potopy & Podlasie & 2014 & 11 \\
\hline Sulęczyno & Pomerania & 2014 & 2 \\
\hline Młodzawy & Świętokrzyskie & 2013 & 292 \\
\hline Oksa & Świętokrzyskie & 2014 & 320 \\
\hline Umianowice & Świętokrzyskie & 2013 & 4 \\
\hline Wiązownica Kolonia & Świętokrzyskie & 2014 & 24 \\
\hline Wólka Bodzechowska & Świętokrzyskie & 2014 & 98 \\
\hline Borków & Świętokrzyskie & 2014 & 238 \\
\hline Sokolica & Warmia-Mazury & 2014 & - \\
\hline Jezioro Liptowskie & Western Pomerania & 2013 & single specimens \\
\hline Jezioro Tuczno & Western Pomerania & 2013 & $>10$ \\
\hline Mechowisko Mannowo & Western Pomerania & 2014 & 4 \\
\hline Debrzynka & Wielkopolska & 2013 & $>10$ \\
\hline Dolina Szczyry & Wielkopolska & 2013 & $>10$ \\
\hline Flinta & Wielkopolska & 2013 & $>10$ \\
\hline Samborka I & Wielkopolska & 2013 & $>10$ \\
\hline Samborka II & Wielkopolska & 2013 & $>10$ \\
\hline Skic Va 1 & Wielkopolska & 2018 & $\bullet$ \\
\hline Skic Va 2 & Wielkopolska & 2018 & • \\
\hline Skic Va 3 & Wielkopolska & 2018 & • \\
\hline
\end{tabular}




\section{DISCUSSION}

The population densities at all the sites of $V$. moulinsiana in Skic are very high: indeed, locality Vm 2 supports the largest numbers of this species in Poland. However, comparison of these populations with others from Poland based on GIOŚ data may not be reliable, because the present study was carried out at a different time. The indicator assessments done by the Polish State Environmental Monitoring Programme (LIPIŃSKA et al. 2012) were based on data collected in late summer (August-September), when the snails are at their most active and are most easily seen on the vegetation. This is also the period when juveniles appear and when densities reach their peak values during the season according to the population dynamics pattern described by LIPIŃSKA et al. (2012; manuscript submitted). Thereafter, the number of adults decreases dramatically, while the proportion of juveniles increases. It is not known whether in the summer, during the expected population peak, the populations at the Skic localities were even more abundant than those recorded in November, whether or not the population dynamics in this area follows the pattern described for this species (LiPIŃSKA et al. 2012; manuscript submitted) and whether such a peak does not occur or is displaced in time.

The weather anomalies recorded during the fieldwork may have been responsible for the appearance of such high numbers of these snails. At that time the weather conditions were favourable for snails: unusually high air temperatures for November and also high air humidity levels. If climate change is indeed the cause, the increasingly frequent weather anomalies we are experiencing may eventually disrupt the functioning of this and other populations. The pattern of $V$. moulinsiana population dynamics may also change elsewhere in Poland.

The positions of these populations relative to each other (along the Skicka Struga River) imply that they may be functioning within a metapopulation system: though discrete, they are mutually dependent on each other (SOLARZ 1998). It is impossible, however, to assess the nature of these dependencies on the basis of just one field visit. Another possibility is that we are dealing with a source-sink system, where one of the populations is a source for the colonisation of other sites that could not exist without this source (SOLARZ 1998), but in the absence of detailed research this cannot be stated unequivocally. Therefore, when decisions are to be made regarding the development of this area, care should be taken to ensure a continuity of contact between these populations that is as close as possible to the current one. A third possibility is that this population is a single, continuous one, but whose distribution is such that it appears to be a metapopulation system. Resolving this issue will require wide-ranging research.

Up till 2014, $135 \mathrm{~V}$. angustior sites were known in Poland. Their number is constantly growing, however, as a result of a very considerable inventory effort and increasing knowledge about this species and its preferred habitat types. It is not as rare a species in the Polish fauna as was thought a few years ago. North-western Poland is where most of the national localities of $V$. angustior are situated (KSIĄŻKIEWICZ 2008, results of species monitoring in 2013-2014; data provided by GIOŚ). Since there are many sites where the population density reaches several dozen or even several hundred individuals per square metre, sites where the population status is defined as poor are probably less important for the conservation of this species in Poland. Despite this finding specimens suggesting the species' occurrence in the area is noteworthy. The new site of $V$. moulinsiana (locality $\mathrm{Vm}$ 2) is certainly extremely valuable for the fauna of Poland and should be included in the list of sites monitored by the Polish State Environmental Monitoring GIOŚ Programme. The study plot is extremely valuable simply because two priority snail species in Poland's malacofauna are present there. It is likely that a malacological inventory of the entire Bory Kujańskie area would reveal many more sites of these species.

\section{ACKNOWLEDGEMENTS}

This study was partly financed by the statutory funds of the Institute of Nature Conservation, Polish Academy of Sciences. 


\section{REFERENCES}

GŁOWACIŃSKI Z. (ed.) 2002. Czerwona Lista Zwierząt Ginących i Zagrożonych w Polsce. Instytut Ochrony Przyrody Polskiej Akademii Nauk, Kraków.

KILLEEN I. J. 2003. Ecology of Desmoulin's Whorl Snail. Conserving Natura 2000 Rivers Ecology Series No. 6. English Nature, Peterborough.

KilleEN I., MOORKENS E., SEDDON M. 2011. Vertigo moulinsiana (errata version published in 2018). The IUCN Red List of Threatened Species 2011: e.T22939A128409843. Downloaded on 10 January 2020.

KSIĄŻKIEWICZ Z. 2008. The narrow-mouthed whorl snail Vertigo angustior (Pulmonata: Gastropoda: Vertiginidae) - distribution and habitat disturbance in northwestern Poland. Tentacle 16: 5-6.

KSIĄŻKIEWICZ Z. 2009. New localities of Vertigo moulinsiana (Dupuy 1849) (Gastropoda: Pulmonata: Vertiginidae) in northwestern Poland. Folia Malacologica 17: 219222.

LIPIŃSKA A. M. 2010. Poczwarówka jajowata Vertigo moulinsiana - rzadki gatunek ślimaka chroniony Dyrektywą Siedliskową. Chrońmy Przyrodę Ojczystą 66: 482-490.

LIPIŃSKA A., KSIĄŻKIEWICZ Z., ZAJĄC K., BARGAWIĘCŁAWSKA J. A. 2012. Poczwarówka jajowata Vertigo moulinsiana. In: MAKOMASKA-JUCHIEWICZ M., BARAN P. (ed.). Monitoring gatunków zwierząt. Przewodnik metodyczny. Część II. GIOŚ, Warszawa, pp. 463-481.
POKRYSZKO B. M. 2004. Vertigo moulinsiana (Dupuy, 1849). Poczwarówka jajowata. In: GŁOWACIŃsKI Z., NOWACKI J. (eds). Polska Czerwona Księga Zwierząt. Bezkręgowce. Instytut Ochrony Przyrody PAN, Kraków, pp. 324-325.

POKRYSZKO B. M., RUTA R., KSIĄŻKIEWICZ-PARULSKA Z. 2016. The first record of Vertigo geyeri Lindholm, 1925 (Gastropoda: Pulmonata: Vertiginidae) in NorthWestern Poland. Folia Malacologica 24: 63-68.

RUTA R., GRUSZKA W., RogALA S., ŻUK K. 2014. Walory przyrodnicze Borów Kujańskich. Przegląd Przyrodniczy 25: 3-75.

SOLARZ W. 1998. O źródłach i ujściach: co nowego w ekologii populacji. Wiadomości Ekologiczne 44: 181-194.

TATTERSFIELD P., MCINNES R. J. 2003. Hydrological requirements of Vertigo moulinsiana. English Nature Research Report No. 549. Northminster House, Peterborough.

USTAWA 2004. Ustawa $\mathrm{z}$ dnia 16 kwietnia 2004 roku o ochronie przyrody. Dz. U. 2004, Nr 92, poz. 880.

WIKTOR A. 2004. Ślimaki lądowe Polski. Mantis, Olsztyn.

Received: March 3rd, 2020

Revised: May 26th/June 8th, 2020

Accepted: June 26th, 2020

Published on-line: July 17th, 2020 